\title{
Social Enterprises Empowerment Through Intellectual Capital Development: A Case Study During Pandemic
}

\author{
Ni Putu Sri Harta Mimba ${ }^{1, a^{*}}$, I Gusti Ayu Made Asri Dwija Putri ${ }^{1, b}$, Anak Agung Ngurah \\ Agung Kresnandra ${ }^{1, c}$ \\ ${ }^{1)}$ Accounting Departement, Faculty of Economics \& Business, Universitas Udayana \\ J1 P.B Sudirman, Denpasar, Bali, Indonesia \\ e-mail: ${ }^{a}$ p.mimba@unud.ac.id, bigamasri@yahoo.com \\ * Corresponding Author
}

\begin{abstract}
During the pandemic period, government and society regard that social enterprises have more increasing role to reduce socials problems. Hence, there is an increased need to empowering social enterprises. This empowerment elevates their added value and competitiveness developing and improving their intellectual capital. However, the study on such development is not yet much explored. This study aims to fill this gap, especially in mapping the quality development of human, customer and structural capitals based on Resource Based Theory (RBT). The good quality of intellectual capital can enlarge the added value and competitiveness of social enterprises. This study is also developing the quality of intellectual capital to empowering social enterprises. This study used convenience sampling technique and obtained sample of 38 social enterprises. Quality mapping analysis and mean analysis are used to analyze the quality of each element of intellectual capital. This study finds that customer capital has the best development (mean score 166.9) followed by human capital (mean score 151.2) and then structural capital (mean score 145). This study also provides the mapping of some parts in the element of human, customer and structural capitals that require further improvements. and possible solutions that doable and fruitful for social enterprises.
\end{abstract}

Keywords: Intellectual capital development; Pandemic; Resource-based theory; Social enterprise empowerment; Quality mapping analysis

Article History: Received: October 202020 Revised: October 292020 Accepted: November 22020 How to cite: Mimba, N., P., S., H., Putri, I.,G.,M.,A.,D., \& Kresnandra, A.,A.,N.,A. 2020. Social Enterprises Empowerment Through Intellectual Capital Development: A Case Study During Pandemic. Akrual: Jurnal Akuntansi (JA). 2020; 12(1): 1-5. DOI: https://doi.org/ 10.26740/jaj.v12n1.p94-106.

\section{INTRODUCTION}

The characteristics of social enterprises are said to be unique because they combine social and business aspects. This can have an impact on the implementation of their intellectual capital. Geographical factors can also play a role. Bali in particular, spiritual capital can be considered as an element of intellectual capital. The same thing can also be found in West Nusa Tenggara and East Nusa Tenggara. Palmer et al. (2013) define spiritual capital as individual and collective capacities generated through affirming and maintaining the intrinsic spiritual value of every human being. With its focus on social and profit, a social enterprise must be financially healthy to survive and be able to reduce social problems, especially poverty. 
A social enterprise is expected to be able to solve social problems by developing a company to get a good profit. During covid-19 outbreaks, both government and society regard that social enterprises have more increasing role to decrease socials problems. For this reason, there is an increased need to empowering social enterprises. This empowerment can escalate their added value and competitiveness by developing their intellectual capital.

Social entrepreneurs can create job opportunities and improve people's lives. In addition, it can provide innovation and new creation values to the socio-economic environment of society, can become the social capital of national development, and help efforts to increase equality (equity promotion) and distribute welfare to the wider community. Social enterprises face various challenges, including funding problems, and the lack of incentives provided by the government to ease the burden on institutions engaged in the social sector. Therefore, Social Enterprises must be supported by institutional empowerment.

In contrast to developed countries, social enterprise empowerment in developing countries is still not widely known by the public, while on the other hand, existing social enterprises experience many challenges, especially in terms of financial performance in their companies. One of the ways to empowering social enterprises is through developing their intellectual capital that consists of three elements, namely: human capital, relational capital, and structural capital (Sawarjuwono \& Kadir, 2003; Stewart \& Ruckdeschel, 1998; Sveiby 1997; Saint-Onge, 1996; Bontis, 2000). Marr \& Schiuma (2001) define intellectual capital as a group of knowledge assets that are associated with an organization and which most significantly contribute to increasing the added value of the organization and increasing its competitive value.

The development and management of intellectual capital and an effective management are the key to the success of an organization. This also applies to the type of organization that is currently being developed, namely the social enterprises. Currently the government is paying great attention to social enterprises in line with the industrial revolution 4.0. Companies that are included in social enterprises emphasize not only the profit aspect, but also the sustainable social aspect. Its strategic role in reducing various social problems will be maximally achieved if it is supported by the development of adequate intellectual capital or social capital. In contrast to the important role of social enterprises which are now increasingly being recognized by the government and society, currently studies on how to develop intellectual capital (IC) for empowering social enterprises in the industrial era 4.0 are still relatively limited. This study is trying to fill this gap. Based on this, the specific objectives of this study are as follows:

1) Obtain empirical evidence on social enterprise empowerment through the development of intellectual capital in the industrial era 4.0.

2) Develop several indicators from the three elements of IC which include elements of human capital, structural capital, and relationship capital. This will provide a more comprehensive current picture for social enterprise actors.

There are many social problems faced by developing countries such as Indonesia, such as high levels of poverty, high unemployment, and frequent traffic jams. What can be a solution to these social problems is the empowerment of social enterprises. A social enterprise is expected to be able to solve social problems by developing a company to get a good profit. In contrast to developed countries, social enterprise empowerment in 
developing countries is still not widely known by the public, while on the other hand, existing social enterprises experience many challenges, especially in terms of financial performance in their companies. One of the ways to empower a social enterprise is through developing intellectual capital.

Intellectual capital is important to companies because it helps drive success and create value. Some examples of intellectual capital that could lead to this outcome are the right skills and knowledge, a good company brand and reputation, strong relationships with major suppliers, ownership of customer and market data, and a culture of innovation (Marr, 2008; Cahyono \& Qomariah, 2017; Bontis et al., 2000).

Intellectual capital development from a management accounting point of view, Marr (2008) states that the process of identifying intellectual capital owned by a company can be done by following the guidelines below.
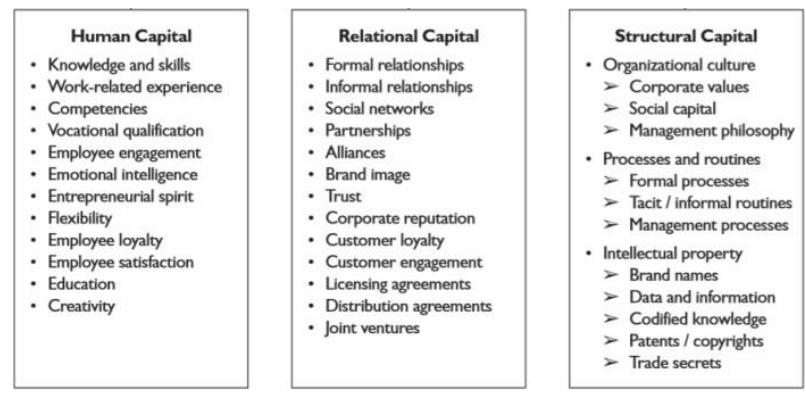

Figure 1. Guidelines for the Identification of Intellectual Capital

Next, it is followed by evaluating the strategic value of intellectual capital. This step can provide insight into whether the company is investing too much or underinvesting in certain areas.

Effective management in the development and management of intellectual capital is the key to the success of an organization. This also applies to the type of organization that is currently being developed, namely the social enterprise. Currently the government is paying great attention to social enterprises in line with the industrial revolution 4.0. Companies that are included in social enterprises emphasize not only the profit a spect, but also the sustainable social aspect. Its strategic role in reducing and starting various social problems will be maximally achieved if it is supported by the development of adequate intellectual capital or social capital. This will also determine whether the development of social enterprises in Indonesia will become a panacea (i.e. a very potent drug) in the industrial revolution 4.0.

Resource Based Theory (RBT) is a theory related to intellectual capital. This RBT theory was first introduced by Wernerfelt (1984). This theory suggests that a company that can manage its resources and knowledge well will have a competitive advantage that affects company performance. The competitive advantage of a company lies in the effective ownership and utilization of organizational resources that can add value, rare, difficult to imitate (imperfectly imitable), and are not replaced by other resources (nonsubstitutable). The strategic resource is Intellectual Capital (IC).

Currently, studies that discuss social enterprise empowerment in Indonesia, especially in Indonesia, are still relatively limited. On the one hand, social problems in 
Indonesia are still high, including inside and outside of Bali Island. Therefore, social enterprise empowerment is very necessary, because it will be able to encourage the creative economy.

One way of empowering a social enterprise and improving its performance is through developing intellectual capacity. However, currently there are not many social enterprises that can develop intellectual capital to improve their performance. This study aims to fill that gap.

\section{RESEARCH METHOD}

The object of research is the development of intellectual capital in accordance with the concept of blue economy. This development uses an alternative management accounting system approach so that the results of the study can help social enterprise actors identify IC, map IC triggers, measure, manage and report IC more accurately.

The approach used in this research is an associative quantitative approach. (Sugiyono, 2018), argues that associative research is research that has the aim of knowing the relationship between two or more variables. This study aims to determine the effect of the independent variables on the dependent variable.

The population of this research is all social enterprise actors. The sampling technique used in this study is nonprobability sampling, namely the sampling technique does not provide equal opportunities or opportunities for each element or member of the population to be selected as samples (Sugiyono, 2018). Part of the nonprobability sampling technique used in this study is the purposive sampling method, which means that there is a specific purpose in selecting samples not randomly. Purposive sampling is a sampling technique that is carried out with the desired criteria. The sample in this study used social enterprises in Bali and outside Bali.

The data used in this research are quantitative and qualitative data. Quantitative data is considered qualitative data (Sugiyono, 2018: 14). The quantitative data in this study is a variety of information obtained from distributing questionnaires. Sugiyono, (2018). The qualitative data used in this study is the number of social enterprises in Bali. Primary data is data obtained directly from the source, observed, recorded for the first time (Sugiyono, 2018). The primary data that will be used in this study are the results of the questionnaire answers (attached) and are quantified using a 5-point Likert scale. The research respondents are all social enterprises in Bali and outside Bali.

This study uses observational data collection techniques and questionnaires. Before distributing the research questionnaire to the real respondents, it was first tested the validity and reliability of the questions. Validity tests are used to determine the reliability of questions to reveal information. The validity test was carried out using the product moment correlation.

The object of research is the development of intellectual capital in accordance with the concept of blue economy. This development uses an alternative management accounting system approach so that the results of the study can help social enterprise actors identify IC, map IC triggers, measure, manage and report IC more accurately.

The approach used in this research is an associative quantitative approach. (Sugiyono, 2018: 64), argues that associative research is research that has the aim of knowing the relationship between two or more variables. This study aims to determine the effect of the independent variables on the dependent variable. 
The population of this research is all social enterprise actors. The sampling technique used in this study is nonprobability sampling, namely the sampling technique does not provide equal opportunities or opportunities for each element or member of the population to be selected as samples (Sugiyono, 2018). Part of the nonprobability sampling technique used in this study is the purposive sampling method, which means that there is a specific purpose in selecting samples not randomly. Purposive sampling is a sampling technique that is carried out with the desired criteria. The sample in this study used social enterprises in Bali and outside Bali.

The data used in this research are quantitative and qualitative data. Quantitative data is considered qualitative data (Sugiyono, 2018: 14). The quantitative data in this study is a variety of information obtained from distributing questionnaires. Sugiyono, (2018). The qualitative data used in this study is the number of social enterprises in Bali. Primary data is data obtained directly from the source, observed, recorded for the first time (Sugiyono, 2018). The primary data that will be used in this study are the results of the questionnaire answers (attached) and are quantified using a 5-point Likert scale. The research respondents are all social enterprises in Bali and outside Bali.

This study uses observational data collection techniques and questionnaires. Before distributing the research questionnaire to the real respondents, it was first tested the validity and reliability of the questions. Validity tests are used to determine the reliability of questions to reveal information. The validity test was carried out using the product moment correlation.

Reliability test is used to measure a question which is an indicator of a variable or construct and is reliable, reliable and accurate. Reliability testing uses Cronbach's alpha coefficient. The instrument is called reliable if its Cronbach alpha value is greater than 0.06 .

According to Sugiyono (2018: 206) descriptive analysis is: "Statistics are used to analyze data by describing or describing the data that has been collected as it is without intending to make general conclusions or generalizations". Descriptive analysis is a research conducted to determine the value of the independent variable and the dependent variable.

The data analysis technique used in this research is by looking at performance importance analysis and mean analysis. If the resulting value exceeds the average value, then the development of the intellectual capital element has gone well

\section{RESULTS AND DISCUSSION}

The population in this study were all social enterprise actors. The sample in this study used social enterprises in Bali and outside Bali. The sample of this study consisted of 33 social enterprise actors located in Bali, 3 respondents located in Jakarta, 1 respondent located in Banten and 1 respondent located in South Tanggerang. After checking, all respondents (38 entrepreneurs) filled out the questionnaire completely. From the results of the questionnaire obtained data about the demographic characteristics of respondents such as education level, position, length of work in the company, gender, company area. 
Mimba, Putri, \& Kresnandra, Social Enterprises Empowerment....

Table 1. Respondent's Characteristics

\begin{tabular}{|c|c|}
\hline Items & Percentage \\
\hline \multicolumn{2}{|l|}{ Gender } \\
\hline Male & $68,4 \%$ \\
\hline Female & $31,6 \%$ \\
\hline \multicolumn{2}{|l|}{ Age } \\
\hline 21-25 Years Old & $7,9 \%$ \\
\hline 26-30 Years Old & 0 \\
\hline 31-35 Years Old & $2,1 \%$ \\
\hline 36-40 Years Old & $10 \%$ \\
\hline 41-45 Years Old & $6,8 \%$ \\
\hline 46-50 Years Old & $58,4 \%$ \\
\hline 51-55 Years Old & $4,2 \%$ \\
\hline 56-60 Years Old & $2,6 \%$ \\
\hline \multicolumn{2}{|l|}{ Level of Education } \\
\hline Senior High School & $2,6 \%$ \\
\hline Diploma & $31,6 \%$ \\
\hline Bachelor's Degree & $47,4 \%$ \\
\hline Master's Degree & $13,2 \%$ \\
\hline Doctoral Degree & $5,3 \%$ \\
\hline \multicolumn{2}{|l|}{ Position in The Company } \\
\hline \multicolumn{2}{|l|}{ Owner } \\
\hline Manager & $75,7 \%$ \\
\hline Supervisor & $21,6 \%$ \\
\hline Length of Work in the & $2,7 \%$ \\
\hline \multicolumn{2}{|l|}{ Position } \\
\hline Less than a year & $7,9 \%$ \\
\hline 1-2 Years & $10,5 \%$ \\
\hline 3-5 Years & $13,2 \%$ \\
\hline More than 5 years & $68,4 \%$ \\
\hline \multicolumn{2}{|l|}{ Business Area } \\
\hline Bali & $86,8 \%$ \\
\hline Jakarta & $7,8 \%$ \\
\hline Banten & $2,6 \%$ \\
\hline South Tangerang & $2,6 \%$ \\
\hline
\end{tabular}

Source: Data Processed, 2020

Validity tests are used to determine the reliability of questions to reveal information. The validity test is done by using the product moment correlation. The results of the Validity Test are shown in Table 2. 
Table 2. Validity Test Result

\begin{tabular}{|c|c|c|c|}
\hline No & Statements & $\begin{array}{l}\text { Sig-2 } \\
\text { Tailed }\end{array}$ & $\begin{array}{l}\text { Pearson } \\
\text { Correlation }\end{array}$ \\
\hline 1 & The quality of ideas submitted by employees & 0.000 & 0.674 \\
\hline 2 & $\begin{array}{l}\text { Benefits of training programs that have been provided } \\
\text { to employees }\end{array}$ & 0.000 & 0.732 \\
\hline 3 & The quality of cooperation made by employees & 0.000 & 0.591 \\
\hline 4 & $\begin{array}{l}\text { Improved employee skills compared to when initially } \\
\text { hired }\end{array}$ & 0.026 & 0.360 \\
\hline 5 & $\begin{array}{l}\text { The employee recruitment program is carried out } \\
\text { comprehensively covering all units in the company }\end{array}$ & 0.000 & 0.645 \\
\hline 6 & $\begin{array}{l}\text { The consequences for the company if employees in } \\
\text { important positions stop working }\end{array}$ & 0.000 & 0.631 \\
\hline 7 & The ability of employees to come up with new ideas & 0.000 & 0.627 \\
\hline 8 & The ability of employees to voice their opinions & 0.002 & 0.484 \\
\hline 9 & Individual abilities to learn from each other & 0.000 & 0.647 \\
\hline 10 & $\begin{array}{l}\text { The ability of employees to give their best results for } \\
\text { the company }\end{array}$ & 0.000 & 0.795 \\
\hline 11 & The level of employee satisfaction with the company & 0.000 & 0.558 \\
\hline 12 & Employees always try to work optimally & 0.004 & 0.456 \\
\hline 13 & $\begin{array}{l}\text { Employees always make decisions through careful } \\
\text { consideration }\end{array}$ & 0.000 & 0.547 \\
\hline 14 & Employees always work with passion & 0.000 & 0.577 \\
\hline 15 & $\begin{array}{l}\text { Employees influence each other by showing good } \\
\text { performance }\end{array}$ & 0.000 & 0.636 \\
\hline 16 & $\begin{array}{l}\text { Employees always try to provide the best for the } \\
\text { company }\end{array}$ & 0.000 & 0.736 \\
\hline 17 & $\begin{array}{l}\text { The level of customer satisfaction with the products and } \\
\text { services produced by the company }\end{array}$ & 0.000 & 0.596 \\
\hline 18 & The level of customer loyalty to the company & 0.000 & 0.764 \\
\hline 19 & Current market conditions faced by the company & 0.038 & 0.337 \\
\hline 20 & $\begin{array}{l}\text { The company's ability to achieve the highest market } \\
\text { share today }\end{array}$ & 0.000 & 0.565 \\
\hline 21 & Products produced are market-oriented & 0.000 & 0.716 \\
\hline 22 & $\begin{array}{l}\text { The ability of products produced / services produced to } \\
\text { meet customer needs }\end{array}$ & 0.000 & 0.729 \\
\hline 23 & The company's ability to understand the target market & 0.000 & 0.628 \\
\hline 24 & $\begin{array}{l}\text { The company's ability to consider products that are of } \\
\text { interest to customers }\end{array}$ & 0.000 & 0.658 \\
\hline 25 & The ability to produce what customers want & 0.000 & 0.573 \\
\hline 26 & $\begin{array}{l}\text { The ability to shorten the time for handling customer } \\
\text { complaints }\end{array}$ & 0.000 & 0.657 \\
\hline 27 & $\begin{array}{l}\text { The ability to provide added value to the products } \\
\text { produced }\end{array}$ & 0.000 & 0.631 \\
\hline
\end{tabular}


Mimba, Putri, \& Kresnandra, Social Enterprises Empowerment....

28 The ability to respond to what customers say

$0.001 \quad 0.499$

29 Your assessment of current company database and

0.000

0.728

administrative processes

30 Ability to reduce the cost of producing goods / services

$0.000 \quad 0.633$

31 The amount of salaries that employees currently

0.000

0.511

received is already the best circumstance

32 Time efficiency for customers to make transactions

$0.000 \quad 0.662$

33 The process of producing goods / procurement of

0.000

0.791

services is already running with minimum production costs

34 The ability of administrative / financial systems and

$0.000 \quad 0.734$

procedures to implement new ideas

35 Ability to support the development of new ideas

36 Ability to develop most of the ideas in the industry

37 System and procedure capability in supporting the developed innovation

38 The system's ability to provide easier access to information

39 The quality of administrative activities currently undertaken has an easy bureaucracy

40 Placement of racks between machines / supporting equipment in the production process / production service is not far from each other

Source: Data Processed, 2020

The results of the validity test show that all items have a sig 2 tailed value $<0.05$ and a positive pearson correlation value, so the questionnaire is declared valid.

\begin{tabular}{|c|c|}
\hline Cronbach's Alpha & $\mathrm{N}$ of Items \\
\hline .955 & 40 \\
\hline
\end{tabular}

Based on the reliability test data mentioned above, it is known that it has a value of 0.955 . Whereas in the Cronbach's Alpha method, a measuring instrument is defined reliable when the coefficient obtained is $>0.6$. Hence, it can be seen that the measuring instrument used by the author is real. The questionnaire contains about 40 statements (human capital = 16; customer capital $=11$; Structural Capital $=13$ ) which are filled in by applying the 5 Likert scale filling method, with criteria $1=$ very bad; 2 = bad; $3=$ enough; $4=$ good, and $5=$ very good. The respondents of the questionnaire are owners, managers and supervisors. The results of the questionnaire are described in the following table. 
Table 4. Questionnaire Results

\begin{tabular}{|c|c|c|c|c|}
\hline No & Question & $\begin{array}{l}\text { Average } \\
\text { Value Per } \\
\text { Element }\end{array}$ & $\begin{array}{l}\text { Most } \\
\text { Respondents' } \\
\text { Choice } \\
\end{array}$ & Percentage \\
\hline 1 & $\begin{array}{l}\text { I. Human Capital } \\
\text { Quality of ideas submitted by } \\
\text { employees }\end{array}$ & 3.82 & 4 & 50 \\
\hline 2 & $\begin{array}{l}\text { Benefits of training programs that } \\
\text { have been provided to employees }\end{array}$ & 4.05 & 4 & 63.2 \\
\hline 3 & $\begin{array}{l}\text { The quality of cooperation made } \\
\text { by employees }\end{array}$ & 4.21 & 4 & 52.8 \\
\hline 4 & $\begin{array}{l}\text { Improved employee skills } \\
\text { compared to when initially hired }\end{array}$ & 4.24 & 4 & 47.4 \\
\hline 5 & $\begin{array}{l}\text { The employee recruitment program } \\
\text { is carried out comprehensively } \\
\text { covering all units in the company }\end{array}$ & 3.89 & 4 & 52.6 \\
\hline 6 & $\begin{array}{l}\text { The consequences for the company } \\
\text { if employees in important positions } \\
\text { stop working }\end{array}$ & 3.47 & 3 & 50 \\
\hline 7 & $\begin{array}{l}\text { The ability of employees to come } \\
\text { up with new ideas }\end{array}$ & 3.76 & 4 & 42.1 \\
\hline 8 & $\begin{array}{l}\text { The ability of employees to voice } \\
\text { their opinions }\end{array}$ & 3.79 & 4 & 50 \\
\hline 9 & $\begin{array}{l}\text { Individual abilities to learn from } \\
\text { each other }\end{array}$ & 3.92 & 4 & 60.5 \\
\hline 10 & $\begin{array}{l}\text { The ability of employees to deliver } \\
\text { their best results for the company }\end{array}$ & 4.16 & 4 & 52.6 \\
\hline 11 & $\begin{array}{l}\text { The level of employee satisfaction } \\
\text { with the company }\end{array}$ & 4.11 & 4 & 63.2 \\
\hline 12 & $\begin{array}{l}\text { Employees always try to work } \\
\text { optimally }\end{array}$ & 4.13 & 4 & 57.9 \\
\hline 13 & $\begin{array}{l}\text { Employees always make decisions } \\
\text { through careful consideration }\end{array}$ & 3.87 & 4 & 65.8 \\
\hline 14 & $\begin{array}{l}\text { Employees always work with } \\
\text { passion }\end{array}$ & 4.08 & 4 & 68.4 \\
\hline 15 & $\begin{array}{l}\text { Employees influence each other by } \\
\text { showing good performance }\end{array}$ & 4.03 & 4 & 57.9 \\
\hline 16 & $\begin{array}{l}\text { Employees always try to provide } \\
\text { the best for the company } \\
\text { II. Customer Capital }\end{array}$ & 4.13 & 4 & 63.2 \\
\hline 17 & $\begin{array}{l}\text { The level of customer satisfaction } \\
\text { with the products and services } \\
\text { produced by the company }\end{array}$ & 4.32 & 4 & 47.4 \\
\hline 18 & $\begin{array}{l}\text { The level of customer loyalty to the } \\
\text { company }\end{array}$ & 4.37 & 5 & 47.4 \\
\hline
\end{tabular}


19 Current market conditions faced by the company

20 The company's ability to achieve the highest market share today

21 Products produced are marketoriented

22 The company's ability to understand the target market

23 The company's ability to consider products that are of interest to customers

24 Ability to produce what customers want

25 The ability to shorten the time for handling customer complaints

26 The ability to provide added value to the products produced

27 The ability to respond to what customers request

\section{Structural Capital}

28 Your assessment of the current administration processes and company data base

29 Ability to reduce the cost of producing goods / services

30 The amount of salaries that employees currently receive are the best

31 Time efficiency for customers to make transactions

32 The process of producing goods / procurement of services is already running with minimum production costs

33 The ability of administrative / financial systems and procedures to implement new ideas

34 Ability to support the development of new ideas

35 Ability to develop most of the ideas in the industry

36 System and procedure capability in supporting the developed innovation

37 The system's ability to provide easier access to information 
38 The quality of administrative activities currently undertaken has an easy bureaucracy

39 Placement of racks between machines / supporting equipment in the production process / production service is not far from each other

40 Work atmosphere
3.82

4

50

4

60.5

4.32

4

47.4

Source: Data Processed, 2020

Based on the data mentioned in Table 4, the element that has the highest average on human capital items is the increase in employee skills compared to when they were initially hired with an average value of 4.24. On the other hand, the lowest average on human capital items is a 'consequence for the company if employees in important positions stop working' with an average value of 3.47. This can be overcome through the proper transferring of experience and knowledge between employees. It can be helpful to have a team in doing a task. Hence, it is expected that a company will still have a backup employee if the current employee is resigning. In addition, the information related to a task has to be keeping in a good database. The element with the second lowest average in the human capital items is the 'ability of employees to come up with new ideas' which have an average value of 3.76. This situation can be managed by having a friendlier situation between a manager and owner with her/his employees. This can lead to a willingness to communicate from employees' side. Another way to handle this is to register the employees to follow some workshops to enhance their knowledge.

Related to the customer capital item based on Table 4 the elements that have the lowest average is the current market conditions faced by companies that have a value of 3.18. The element that has the second lowest average on customer capital items is the company's ability to gain the highest market share today with an average value of 3.39. These two lowest elements are currently faced by most of enterprises, including social enterprises due to the covid-19 outbreaks. The customer capital item element that has the highest average value is the level of customer loyalty to the company which has a value of 4.37.

The element that has the lowest average value on structural capital items is the ability to reduce the cost of producing goods / services with an average value of 3.53. Cost reduction can be achieved by increasing the efficiency of production and marketing. For example, social enterprises have to consider allocating more of their marketing cost for online marketing instead of offline marketing which has a higher level of cost. The second lowest average value on structural capital items is the element of customer time efficiency to make transactions with a value of 3.68. This challenge can be solved to consider using QRIS in the payment procedure. This is also in line with Indonesian Central Bank request to use this online payment method. During the pandemic, QRIS method of payment will increase the customer convenience, as it allows less physical contact. Meanwhile, the highest average value on the structural capital item is the work atmosphere element with a value of 4.32 


\section{CONCLUSION}

Based on the data collected and the results of the discussion, the majority of respondents in this study were 46-50 years old (58.4\%) with the male gender predominantly. The majority of respondents are the owner of the company. This could be due to women played a dual role as housewives, so they probably did not have much time to fill out the questionnaire.

During the pandemic, the government and society consider that social enterprises had an even greater role in reducing social problems. Thus, social enterprises empowerment is indispensable. This empowerment can be done by developing and improving the quality of their intellectual capital. But the study of intellectual capital development for social enterprises has not been widely researched. This study aims to fill the gap, especially in mapping the development of hr quality, customers and structural capital based on Resource Based Theory (RBT). Quality intellectual capital can increase the added value and competitiveness of social entrepreneurship. The study also developed the quality of intellectual capital for the empowerment of social entrepreneurship. The study used convenience sampling techniques to spread questionnaires online to owners, managers and supervisors, and obtained a sample of 38 social enterprises. Quality mapping analysis and average analysis are used to analyze the quality of each element of intellectual capital. The study found that customer capital had the best growth (an average score of 166.9) followed by human capital (an average score of 151.2) and then structural capital (average score of 145). This study also provides the mapping of some parts in the element of human, customer and structural capitals that require further improvements and possible solutions that doable and fruitful for social enterprises.

Recommendation: for academician in mapping the area of intellectual capital that have to be improved and finding the best way to improve it. In addition, the results of this study are applicable mostly for practitioners in developing their intellectual capital, especially for social enterprises. For government, the increasing performance of social enterprise will be more effective to reduce social problems. In the future, it would be beneficial to provide more support for social enterprises, such as by providing more trainings to improve their human capability

\section{ACKNOWLEDGMENT}

The authors wish to express their appreciation to the head of Research and Community Service Unit of Udayana University for supporting and funding this study under the scheme of Udayana Research Excellent.

\section{REFRENCES}

Bontis, N., Keow, W.C.C., \& Richardson, S. (2000). Intellectual capital and business performance in Malaysian industries. Journal of Intellectual Capital, 1(1), 85-100. doi:10.1108/14691930010324188.

Cahyono, D \& Qomariah, N. (2017). Intellectual Capital dan Kinerja Perusahaan. Jember: Cahaya Ilmu. 
Marr, B. (2008). Impacting Future Value: How to Manage your Intellectual Capital. Management Accounting Guideline (MAG) Jointly Published by CMA, AICPA, and CIMA. Retrieved from https://www.journalofaccountancy.com/content/dam/jofa /archive /issues/2008/09/mag-intcapital-eng.pdf

Marr, B., and Schiuma, G. (2001). Measuring and Managing Intellectual Capital and Knowledge Assets in New Economy Organisations, in Bourne, M. (Ed.). Handbook of Performance Measurement, Gee, London.

Saint-Onge, H. (1996). Tacit knowledge the key to the strategic alignment of intellectual capital. Planning Review, 24(2), 10-16. https://doi.org/10.1108/eb054547

Sawarjuwono, T., \& Kadir, A. P. (2003). Intellectual Capital: Perlakuan, Pengukuran dan Pelaporan. Jurnal Akuntansi Dan Keuangan, 5(3), 35-57. Doi: 10.9744/ jak.5.1. pp. $\% 2035-57$

Stewart, T., \& Ruckdeschel, C. (1998). Intellectual Capital: The new wealth of organizations. Performance Improvement, 37(7), 56-59. Doi: 10.1002/pfi. 4140370713

Sugiyono. (2018). Metode Penelitian: Kualitatif, Kuantitatif, dan R \& D. Bandung: Alfabeta.

Sveiby, K.E. (1997). The Intangible Assets Monitor. Journal of Human Resource Costing \& Accounting, 2(1), 73-97. Doi: 10.1108/eb029036

Wernerfelt, B. (1984). A Resource-Based View of the Firm. Strategic Management Journal, 5 (2), 171-180. Retrieved from http://www.jstor.org/stable/2486175 